\title{
Historein
}

Vol 3 (2001)

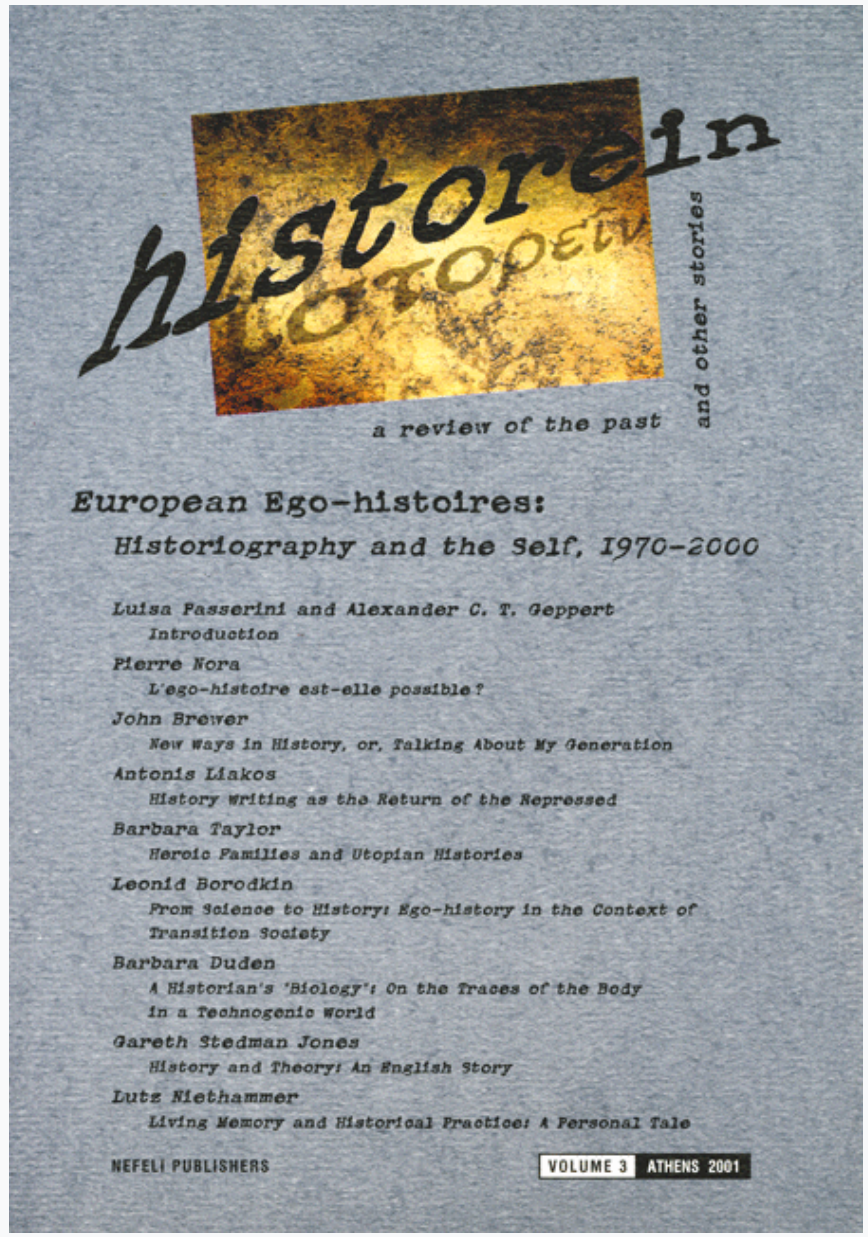

\section{New Ways in History, or, Talking About My Generation}

John Brewer

doi: $\underline{10.12681 / \text { historein.98 }}$

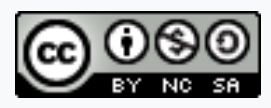

This work is licensed under a Creative Commons Attribution-NonCommercialShareAlike 4.0.

\section{To cite this article:}

Brewer, J. (2002). New Ways in History, or, Talking About My Generation. Historein, 3, 27-46. https://doi.org/10.12681/historein.98 


\section{New Ways in}

\section{History,}

or,

\section{Talking About}

\section{My Generation}

The events surrounding the historian and in which he takes part will underlie his presentation like a text written in invisible ink.

Walter Benjamin ${ }^{1}$

\section{Prologue: Setting Up the Subject}

In the late 1990s I became increasingly interested in historical narrative and its connection to changes in the writing of history since the 1960s. I had not, at first, thought about this as an autobiographical issue until it became clear to me that questions about historical narratives could not be separated from issues about their authors. Besides my first foray into writings on history, an examination of a special edition of the Times Literary Supplement (TLS) of 7 April 1966 entitled "New Ways in History," ${ }^{2}$ I was prompted as much by nostalgia as by scholarship. I remembered the issue as an important moment in my education - I was nineteen, newly arrived at Cambridge University from Liverpool, and studying history - a text that in a few pages encapsulated what was wrong with the writing of history in Britain and sketched out a hopeful future for the aspiring scholar. But, as I scanned the articles more than thirty years later, I was surprised, almost shocked, by my selective memory of their contents. I could recall their attack on traditional history - I had a clear memory of what they were against - but I had largely suppressed their blueprint for the future, replacing it with one that was more acceptable, more in accordance with a narrative I wanted to retell 
both about myself and history before 1968. Rereading "New Ways in History" opened up a box filled to overflowing with detailed and vivid memories of the 1960s and of my experiences as a student and aspiring historian. Why then had I radically misremembered what was, by my own admission, a part of something that was very important to me?

The answer, I think, is that what I read - and had chosen not to recall - was embarrassing to me. As we shall see, what the most influential and important essay in "New Ways in History" advocated was a technocratic, objective, scientized history. It placed enormous weight on the power of social science to liberate historians from tradition, to contribute to an agenda of modernity

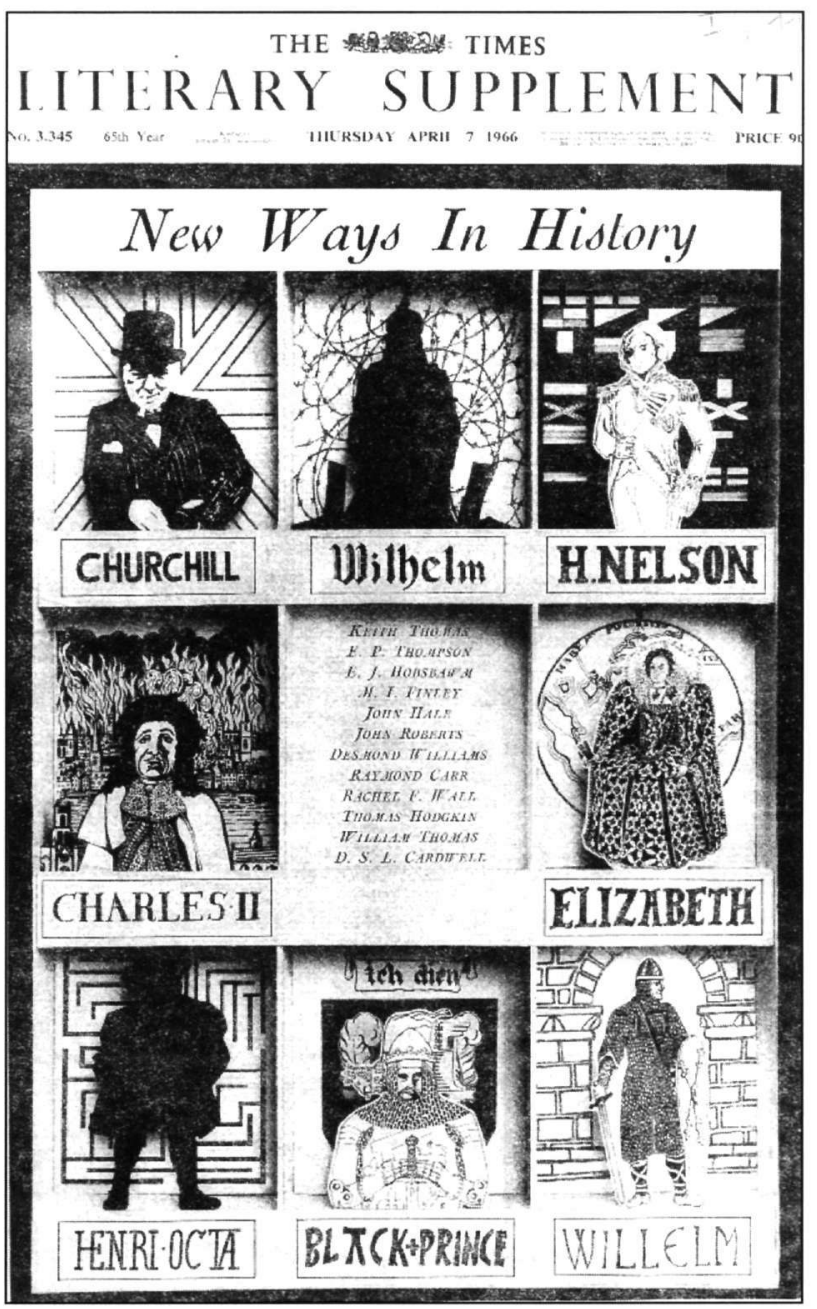

whose end was a more rational egalitarian social order. This history was universalist in many senses - as a science, as having a universal object of inquiry - man or society - in making claims to universal objectivity, and in the priority it accorded to quantities not qualities. However, contained within this history were two powerful desires, some might say longings - a desire for escape and liberation, to end confinement, shake off the mind-forg'd manacles of tradition, write the world anew; and a desire for (virtually total) control expressed in the scientific language of both completeness and precision.

Looked at like this, the cutting edge of the '60s appears laughably old fashioned and unsophisticated. Nowadays, historians who think them-

selves in the vanguard of historical inquiry worry far more about subjectivity than objectivity, tend to see claims to scientific history as epistemologically naïve, speak of histories not history, view knowledge as embedded or positional rather than universal and, as this series of articles attests, demand a high level of self-reflection or reflexivity on the part of the history producer. 
Of course my embarrassment in reading the views of "New Ways in History" stems not from their content but the realization (which I still resist) that they were once my own. I don't, however, want to make this into a story about the victory of history over memory, but rather use the engagement of history and memory to open up a discussion about the views that I had suppressed. For the more I reflected on them the more conscious I became of how widely disseminated and how ardently they had been embraced before they were, in turn, vilified, and buried from sight. Moreover, the views expressed in "New Ways in History" were by no means confined to the discussion of an academic discipline. On the contrary, they flourished both in the pop culture and leftist politics of the 1960s, albeit in somewhat different forms.

If the historian's mantra is "always historicize," then we need to understand both the particular appeal and purchase of social scientific history in Britain in the 1960s. My story has three registers, the personal, the cultural and the political. In all three I want to examine the '60s preoccupation with technocratic science, the transformation of the universal historical subject (as well as of the subject of history), and with modernity. And I want to suggest that it might be fruitful to inquire why it was that this period and place might be characterized as one inordinately preoccupied with both liberation and control, with the contradictory impulses of transcending authority and discipline and of wielding an almost unstoppable power.

The version of the '60s I have been alluding to probably seems familiar and strange - familiar about liberation, strange about power. This is, I think, because my story is one that is not concerned (or, at least only tangentially) with 1968, a year whose effect on scholarship about the ' 60 s has been much like that of 1789 on the eighteenth century. '68 and its immediate aftermath saw a radical transformation in the world I seek to describe - one that replaced the universal aspirations of pop and counter culture, and of scientific socialism with the particularist claims of subcultures, identity politics and the new social movements, a shift that was reflected as much in the writing of history as in leftist politics.

In Britain the failure of Labour governments to deliver the promises proffered by social scientific planning and their refusal to condemn the United States' conduct in the Vietnam war, together with a growing recognition that the universalist claims to liberation and power were in fact largely confined to heterosexual white males, largely discredited the pre-' 68 political vision. Rather than seeing this period as leading to the events of 1968, then, I want to stress '68 as a caesura, the moment, rather like 1789 , when the history of the previous decades was to be rewritten.

Though I am not a Freudian, I think there is some justification for seeing the phenomenon I describe as in some sense oedipal. Certainly in my own case it can be seen that way. I had been brought up with two notions of history: my father's, which was conservative, sentimental, privileged, patriotic and imperial, and my uncle's, which was socialist, democratic, didactic and radical. My father, a surgeon who wore a suit and a homburg hat and for a while drove a Bentley, was a pillar of bourgeois probity, who believed in family and duty, and saw history and the museums and art galleries we visited as repositories of tasteful privilege, the remnants of a 
better, because less egalitarian, less turbulent age when Britain's place as "top nation" secured civilization. My uncle, a journalist and writer, and sometime Communist Party candidate, wrote books on children's liberation (in the 1950s!), the children's column for Tribune - where he explained the importance of such figures as the Tolpuddle Martyrs - and a history of the myths used in sex education. He was a bon viveur with long hair, a fine taste in wines, raffish clothing and a succession of debts, mistresses and wives. Each of them, I suppose, personified different versions of the good life: my father as the dutiful Victorian, my uncle (though older) the freedomloving leftist of the 1930s.

Before my adolescence I was a proto-Victorian: I wore stiff collars, and argued in the school debating society that central heating sapped moral fibre and that nuclear arms were necessary if Britain were to remain a great power. I was a model cadet in the school's pseudo-military force, and could take apart and reassemble a Bren Gun in fifteen seconds. But in the early 1960s I left my father for my uncle. I underwent a conversion to Marxism, existentialism, and (I apologize for the bathos) sociology. This was an auto-didactic enterprise - the result of browsing library shelves, reading the left-wing press and watching late-night television. I often exchanged ideas and books with a school friend, now an architect and still, I believe, a Marxist, and we pieced together a world view, creating a bricolage whose fragmentary, not to say contradictory, form was concealed - at least from me - by its powerful critique of the smug bourgeois world I inhabited.

The Marx I read (paradoxically borrowed from a library funded by robber baron and partner of Andrew Mellon, Andrew Carnegie) was not Capital (which I certainly wouldn't have understood) but The Communist Manifesto, The Eighteenth Brumaire, and the newspaper articles he wrote on the revolutionary events of 1848 . Here was not only a whole new political understanding but also a new way of writing history. I was only briefly a Marxist in politics - I was an admirer not a believer, not an adherent of revolutionary politics, and have never been attracted to the sententiousness and high-mindedness found in many political groups, whether on the Left or Right. And I was also soon to discover that Marxist history and social and economic history were not one and the same.

In 1962 I read Colin Wilson's potboiler on existentialism, The Outsider, and experienced something close to a religious conversion. ${ }^{3}$ Over the next five years I read nearly all the authors Wilson discussed - Kierkegaard, Camus, Barbusse, Dostoevsky, Sartre, Nietzsche. I cringe now re-reading Wilson's book and don't think I really understood most of what I read in its aftermath, but I did find existentialism's emphasis on free agency and responsibility, the Nietzschean critique of mindless conformity, the rejection of conventional Christianity, and the emphasis on confronting the absurdity of life the perfect basis for a critique of my bourgeois provincial life.

If Marx provided a politics, and existentialism a blueprint for everyday life, then sociology was the means of social transformation, the weapon with which to slay the Victorians. The rational investigation and analysis of society, cutting through the layers of prejudice and tradition, would liberate us from their amateurism and from the class-bound institutions that had sustained their 
authority. In the pages of such journals as New Society, first published in 1962, could be found or so I thought - the plans for a new society, the means to create a just and free way of life, to achieve modernity.

To achieve this it was necessary to destroy the old values, to remove the Victorian father. It may seem as if I overemphasize Victorianism, but I was surrounded by it. ${ }^{4}$ I lived in a decayed Victorian city, I went to a school founded by (among others) the Gladstone family, an establishment whose ethics were those of Matthew Arnold - a muscular Christianity exemplified in the headmaster's comment that "getting closer to God is heeling the ball cleanly in the rugby scrum" - and whose official history was entitled "Liverpool Gentlemen." The environment was a sanitized mixture of prudery and duty. I had hoped to escape this when I went to university but even there I was to find a sort of Victorianism in the ascendant. ${ }^{5}$

\section{Victorian History}

When I went to Cambridge to study "read" history in 1965 I was in fact following a curriculum that was not very different from the syllabus nearly all historians at Oxbridge had studied over the previous hundred years. English academic history was a Victorian invention - the Oxford School of Modern History (modern meaning since the fall of Rome) was established in 1871, the Cambridge History Tripos in 1873. These two courses were part of the institutionalization of Rankean history in England. They followed the establishment of the Public Records Office (1866), the foundation of the Royal Historical Society (1868), and the publication of the first Historical Manuscripts Commission report on privately held manuscripts $(1870){ }^{6}$

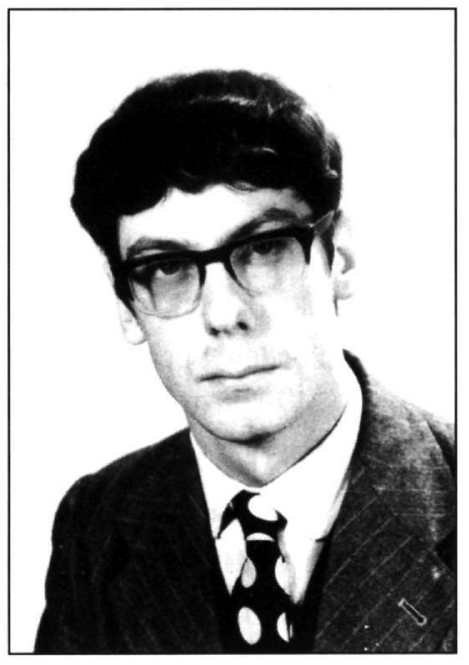

John Brewer in 1967

This Victorian history had a particular content and purpose. Like its model in Germany it sought to apply the rules of evidence to historical documents to reveal the true story that actually happened. Central to its purpose was Quellenforschung - the distinction between potentially misleading secondary materials and primary sources - original documents - whose critical evaluation was the touchstone of historical truth. What counted as an historical document - what ended up in the Public Records Office and in the pages of the reports of the Historical Manuscripts Commission - was material that cast light on the political history and public life of the English nation. What counted as history was primarily political. J. R. Seeley, a key figure in the development of the Cambridge Tripos whose memory is perpetuated in the undergraduate history library that bears his name, wrote, "History is not concerned with individuals except in their capacity as members of a state. That a man in England makes a scientific discovery or 
paints a picture is not in itself an event in the history of England. Individuals are important in history in proportion not to their intrinsic merit, but to their relation to the state." ${ }^{7}$ The hegemonic status of this claim never became clearer than when it finally came under attack. As G. R. Elton put it in 1968, "All forms of history that have existed, exist now, or may yet come to exist belong to the world which the political historian inhabits." ${ }^{8}$

This emphasis on politics and the state was in line with the object of teaching history in the universities that was to shape the sensibility and vision of a (male) ruling elite. (The first essay I wrote at Cambridge, quite typically, was about the so-called "Tudor Revolution in government.") Seeley made it crystal clear, "Our university is, and must be, a great seminary of politicians." 9 Nevertheless, history was not seen as directly instrumental - for its lessons; on the contrary, it was said to be studied "for its own sake." The historian J. R. Green put it this way: History "was looked upon as no special or definitive study, but as part of that general mass of things, which every gentleman should know." ${ }^{10}$ The practice of history (a term and title that G. R. Elton was later to take up in his apologia for this sort of history) - empirical, pragmatic, committed to parliamentary institutions and their history - would shape the moral vision and codes of conduct of magistrates and civil servants, both at home and in the empire. As Herbert Butterfield put it, "I happen to think that history is a school of wisdom and statesmanship."11

It is something of an exaggeration to say that we only studied political and constitutional history. (I had chosen Cambridge over Oxford because the Cambridge Tripos was less antediluvian than the Oxford School.) Economic history was another German import from the turn of the century; there was a strong Cambridge tradition of studying non-European cultures, albeit under the imperial banner of "the Expansion of Europe"; and, because the history course had emerged from a Tripos in moral sciences, we also studied great thinkers from Plato to Marx. But the core of the course was in political and constitutional history - the writings of Maitland and Stubbs and their epigones, and much of our first year course was taken up. with learning how to explicate "gobbets," short passages from such politically important original documents as "The Act in Restraint of Appeals" (1533).

Of course the privilege of doing so made us into an elite. In 1965 only a tiny group of young people went to university (the figure we always quoted was $2 \%$ ), and an even smaller percentage of women. Conversely, in $1964,75 \%$ of sixteen-year-olds and $86 \%$ of seventeen-year-olds were not at school, but either unemployed or working. Yet, though we were very privileged in ways that made us distinctly uncomfortable - did we really need a servant to make our bed for us? it didn't seem as if we belonged to a social elite. Only I, the son of a surgeon, and David Tucker, whose father had a chain of butcher shops in south London, were not receiving a government grant, and most of my contemporaries were not metropolitan (many more from Manchester and, like myself, from Liverpool), were first-generation at university, and came from white-collar and skilled blue-collar backgrounds. Some, like the prodigious Roy Porter, could boast an authentic working-class pedigree. We may have begun the education of nineteenth-century gentlemen, but 
I don't think that any of us saw ourselves as part of a future ruling class, intent on propagating British values to those whom we would later teach and govern. (Which isn't to say that this wasn't what happened to some of us.) Most of us fitted the stereotype of the upwardly mobile beneficiaries of the broadening of school education which was ascribed to the Butler Education Act of 1951. We saw ourselves as the rightful beneficiaries of a growing meritocracy, in a bastion of privilege but there in order to change it.

\section{Cultural Politics}

In my college nearly everyone (except for the evangelical Christians, a tiny, independent group) belonged to one of two broad, opposing coalitions: the labour club and the boat club. The labour club was not a branch of the Labour Party but a loose gathering of socialists, social democrats, Marxists, members of CND (The Committee on Nuclear Disarmament), and the anti-apartheid movement. (I'm not sure if he was actually a member of the group but its most admired figure was Ben Brewster, the translator of Althusser, who stalked the college wearing drab workers clothing rumoured to have been imported from Maoist China.) Similarly the boat club was not so much made up of people who rowed competitively on the river Cam - I knew at least one labour club member who did so - but was a group whose politics were conservative, and who treated university as a traditional finishing school for gentlemen, spending their time in private dining clubs, hunting with beagles, and enjoying sports (but never soccer). One of their number, a keen aficionado of the hounds, was John Patten, later to be Margaret Thatcher's education minister.

These two bodies were divided not only by a fundamental ideological rift - between a traditional Right and modernizing Left - but also by very different conceptions of society, education and self. They spoke, or aspired to speak, Queen's English, we cultivated our regional accents; they wore tweed, we wore corduroy; we prided ourselves on our competence and intelligence, they cultivated insouciance; we believed in equality, they worshipped privilege; we enthusiastically embraced pop culture, they (even if they liked it a bit) saw it as "low." Politics and style were intertwined. Not coincidentally George Melly's history of the period is entitled Revolt into Style. ${ }^{12}$ The cultural politics of the Left in Britain before 1968 were dominated by a number of loosely defined but inter-connected ideas. Though the idea that youth as a social category was not new to the period, the notion of "a generation" was a '60s innovation. Pete Townshend captured it brilliantly in The Who's "My Generation" (1965). This was less a cry for solidarity among a cohort (though it was certainly that) than a cult of youth that emphasized the hostility of the young for their elders:

why don't you all fade away

don't try to dig what we all say...

things they do look awful cold

hope I die before I get old. ${ }^{13}$ 
There was a sense that only those who lived in the (unique) present generation were capable of understanding its dilemmas and desires. My generation, a group that was defined by attitude as well as age, was the site of modernity.

One of my generation's desires was for classlessness. The nuances of class were everywhere in language, education, dress - as well as wealth and power, but there was a naïve, optimistic (and therefore utopian) belief that youth - my generation - could efface these distinctions. For students like us Cambridge exposed the contradictions in this position. We - or perhaps more accurately I (one of the hardest parts of writing this essay is resisting the desire to create a "we" out of an "I") - responded by adopting the newly universal styles and manners of pop culture.

This was not slumming on our part, a traditional pastime of the English élite, though I can't deny that I felt envious of my contemporaries who could claim, like Roy Porter, to be working-class heroes. But I saw the styles of pop culture as an attempt to create a new sort of social world. Pop culture - especially the music industry - was, of course, a quintessential product of affluent capitalism, but it was more than that. Capitalist or not, it was an important innovation that presupposed a different subject and a different aesthetic. It was not mass culture, not working-class culture, not high culture. The key to pop culture was its aggressive erosion of conventional cultural boundaries; it included material and values from high, mass, and sub-cultures, and from all varieties of modernism, which were conveyed through the media of art, music, television, radio and an alternative press. The object was to create a style - one that embraced not only the usual products of creative and artistic endeavour, but life itself. The '60s invented the (what was to become debased) notion of lifestyle.

The key figures of British pop culture did not come, of course, from Cambridge University, but from the art schools, institutions in which painters like Richard Hamilton had invented pop art in the late ' 50 s and which were populated by highly intelligent, rebellious members of the working class, like John Lennon and David Hockney. In my last years at school I used to hang out in the pubs and at the Everyman Theatre close to the Liverpool Art School on Mount Pleasant. (Lest we forget, Alan Ginsburg described Liverpool on his visit there in 1967 as "the centre of the consciousness of the human universe. ${ }^{14}$ )

A figure I regarded with some awe from afar was Adrian Henri, a vast, bearded poet and painter who taught John Lennon, edited a mimeographed poetry magazine called Underdog, staged happenings and mixed media events in the streets, at the art school and the Everyman, and was often to be seen in the pub The Crack with his arm lubriciously around one of the nubile school girls whose charms he celebrated in verse and private conversation. (Henri's website - sadly he died very recently - included the term "babeland.") Henri's 1965 poem (rather like Peter Blake's cover for the Beatles' Sergeant Pepper's Lonely Hearts Club Band) captures many of the varied elements that made up pop culture: 
Paul McCartney Gustav Mahler

Alfred Jarry John Coltrane

Charlie Mingus Claude Debussy

Wordsworth Monet Bach and Blake

Charlie Parker Pierre Bonnard

Leonardo Bessie Smith

Fidel Castro Jackson Pollock

Ghandi Milton Munch and Berg

Bela Bartok Henri Rousseau

Rauschenberg and Jasper Johns

Lukas Cranach Shostakovitch

Kropotkin Ringo George and John

William Burroughs Francis Bacon

Dylan Thomas Luther King

H.P. Lovecraft T.S. Eliot

D.H. Lawrence Roland Kirk

Salvatore Giuliano

Andy Warhol Paul Cezanne

Kafka Camus Ensor Rothko

Jacques Prevert and Manfred Mann

Marx Dostoevsky

Bakunin Ray Bradbury

Miles Davis Trotsky

Stravinksy and Poe

Danilo Dolci Napoleon Solo

St John of the Cross and

The Marquis de Sade
Charles Rennie Mackintosh

Rimbaud Claes Oldenberg

Adrian Mitchell and Marcel Duchamp

James Joyce and Hemingway

Hitchcock and Bunuel

Donald McKinlay Theolonius Monk

Alfred Lord Tennyson

Matthias Grunewald

Philip Jones Griffiths and Roger McGough

Guillaume Apollinaire

Cannonball Adderley

Rene Magritte

Hieronymous Bosch

Stephane Mallarme and Alfred de Vigny

Ernst Mayakovsky and Nicholas De Stael

Hindermith Mick Jagger and Schwitters

\author{
Garcia Lorca \\ and \\ last of all \\ me. $^{15}$
}

Henri's poem speaks to the astonishing heterogeneity of pop culture and the rich variety of resources on which it drew (somewhat indiscriminately) for inspiration: the Romanticism of Wordsworth and Blake; the absurdist and existentialist tradition of Jarry, Camus and Kafka (as mediated in English by the likes of Norman Mailer and Colin Wilson); the anarchism, socialism and pacifism of Marx, Trotsky, Bakunin, Ghandi and Castro; a congeries of twentieth century art movements, above all Dada and surrealism, whose most notable characteristic was their critique of and capacity to outrage bourgeois society; the Beats, above all, Allan Ginsburg and William Burroughs; the modern jazz of Coltrane, Parker, and Monk; and the new scions of pop - Warhol, the Beatles, Napoleon Solo, Jagger and Manfred Mann. Essentially his poem is a catalogue of those who challenged bourgeois ethics, taste and politics, members of a group my father always 
called "the antis." (There are also, of course, some interesting absences: his litany is overwhelming male, including only one woman, Bessie Smith. It seems to me, to push the oedipal point further, that this period was very much about male rebellion against patriarchal authority.)

What Henri celebrates is variety not difference; pop aesthetics were picturesque. In pop culture and in the existentialism and socialism that were its radical fringes the aims were universal and humanist - not about the sort of identity politics that were to emerge in 1968. In as much as they had a political goal it was never about carving out a place in institutionalized politics for different groups in society; it was about creating the conditions in which individuals of every sort could realize their humanity. This was what Charles Taylor has called an expressivist critique of society, one that links the aims and aspirations of this period to the tradition of the Young Hegelians and the young Marx, whose early writings (translated into English in the early '60s by Tom Bottomore) were de rigueur for the Left in this period. ${ }^{16}$ Expressivism was about individual selffulfillment and liberation. As such it occluded problems of social, racial and sexual difference, even as it helped create the conditions that eventually made their analysis a possibility.

My attraction to pop culture was not in the strict sense political. It offered pleasure, noise, colour, movement and light which seemed all the more brilliant when compared with the sepia-coloured Victorianism that suffused the drab, dull, torpid middle-class suburbs of a provincial city like Liverpool in the late 1950s and 1960s. It was certainly a pleasure to pursue pleasure and see it as a sort of virtue - to dress in a pink corduroy suit and Chelsea boots, épater la bourgeoisie, chase girls in the cause of sexual liberation, listen at poetry readings with shop-assistants and dockers in the cause of classlessness, and explain to your parents that your refusal to behave as they wished had a Sartrean justification, or was a rejection of old-fashioned Victorian values. That said, there was a politics of pop, a commitment to modernity, a new historical subject and egalitarianism that was radically at odds with British conservatism.

\section{Socialism, Revisionism, Technology and the Labour Party}

The politics of pop had affinities with what, for convenience's sake, I will call technocratic socialism, a product of the 1960s that most of its proponents have thought best to forget. This was a reformist agenda in as much as it hoped to achieve its ends through existing political parties and structures but presented itself (correctly in my view) as a radical reorganization of British culture.

The key to technocratic socialism was its claim to technical competence, its putative ability to engineer a more egalitarian society by harnessing modern technology and economic management. Its key text was Tony Crosland's The Future of Socialism, published in $1956 .{ }^{17}$ Crosland belonged to a revisionist group of academics and intellectuals within the Labour Party who wished to redefine its objectives. He argued for a reformulation of socialism in the context of the so-called affluent society. Britain in the 1950s, he explained, was no longer an unreconstructed capitalist society of the sort that had existed in the 1930s. It now had a mixed economy, affluent workers - some of whom had bourgeois values, some of whom were white- rather than 
blue-collar - and an industrial structure in which ownership and control were separated with the rise of a managerial class, whose object was to mediate rather than exacerbate the conflict between labour and capital. Implicit in this analysis was the assumption that Labour had to come to terms with/win the votes of groups outside the traditional working class, to become a national rather than sectoral party.

As his critics were quick to point out, Crosland advocated an accommodation with capitalism. In a mixed economy, he argued, Labour governments should rely on "the price mechanism... [as] a reasonably satisfactory method of distributing the great bulk of consumer goods and industrial capital-goods, given the total amount of resources available for consumption and industrial investment." ${ }^{18}$ The object was to manage rather than own the economy (a requirement that demanded special, technical skills) in order to use that growth to pay for burgeoning social expenditure. Labour's challenge to years of Conservative rule lay in its technical expertise and in its willingness to put these to work for an egalitarian agenda.

Crosland's work challenged the economistic assumption that ownership of the means of production necessarily determines the type and form of civil society. He was less interested in fetishising the means to socialism - public ownership - than in defining a series of socialist goals or moral ends which might be achieved in a variety of ways and means. Crosland's goals were equality, the abolition of poverty, full employment, social welfare, and the establishment of community.

In effect what Crosland wanted to achieve was the abolition of social privilege. And he saw the most effective means of achieving these goals as fiscal reform - the aggressive taxation of capital gains and inherited wealth - and education reform - the opening up of high quality and higher education to all ranks of society.

Education was a key plank in the revisionists' platform, both because equal access to education would help achieve the goal of a classless society, but also because changes in education would help create citizens better equipped to change the world. New scientific technologies and the insights of a rigorous though radical social science with an egalitarian agenda would facilitate the transformation of society. Quality education open to all would make competence, merit and ability, rather than privilege and belonging to the old-boy network, the conditions and criteria for success.

The revisionist program sided Labour with modernity. (In its rhetoric it was not unlike Tony Blair's New Labour, though it placed far greater weight on equality than its 1990s successor.) It was linked to a larger impulse which, as we have seen, was sometimes described as anti-Victorian, but more often as anti-establishment. The term "the establishment," though an older coinage, achieved general usage in the 1960s, most notably in Anthony Sampson's enormously influential The Anatomy of Britain (first published in 1962 and then reissued in 1965), which exposed to public view and in meticulous detail the centrality of public school friendships, kinship and old-boy networks in shoring up the system of hereditary privilege that lay at the heart of antiquated, inegalitarian Britain. ${ }^{19}$ 
Crosland's revisionism also shifted emphasis away from old socialist concerns with production and ownership towards an emphasis on consumption and distribution: "Production for use and production for profit may be taken as broadly coinciding now that working class purchasing power is so high. What is profitable is what the consumer finds useful, and the firm and the consumer desire broadly the same allocation of resources. And while paternalists may dislike this allocation, wishing that less were spent on drink and pools and television sets, they must swallow their dislike in the interest of personal freedom." ${ }^{20}$

This emphasis on freedom was characteristic of revisionism. The Labour Party's creation of the welfare state, it was claimed, had achieved Beveridge's aim of freedom from want; now people should not just be free from but free to enjoy their desires. This ran against Labour traditions that were puritanical or hypocritical about sex, and censorious about working-class pleasures that were consumerist or not "improving." (Think, for instance, of Richard Hoggart's threnody on the ills of working-class "flash" in his The Uses of Literacy.) Revisionism shared with pop culture both a critique of the traditional élite and an attachment to a loose kind of hedonism.

Revisionism was a discourse of modernization, but not one that saw modernization in terms of the growth of the market. Rather it saw modernization as the triumph of enlightened rational communication to the end of creating a better, egalitarian civil society. Its aim was to remove the barriers - educational, cultural and social as well as economic - to human realization or self-fulfillment. It was, in many ways, more Habermasian than Marxist or market-oriented.

The appeal of revisionism - certainly to me and I think to many others - lay in its emphasis on modernity, its ideological flexibility and its liberal refusal to overlook human desire. Of course many revisionists were conservative in their views of foreign policy - few were unilateralists or supporters of the "third way" - and to many they represented a politics of meliorism and welfarism - prolonging the life of capitalism by making it more palatable. But in their emphasis on reformism and a society of merit, they addressed a widely-perceived problem, just as in their shift from production to consumption they captured an important change in Britain away from postWorld War II austerity.

By the early 1960s, and not least because of revisionist influence, the Labour Party had been largely revamped as the party of modernity and science. A series of position papers - Labour in the '60s, Signposts of the '60s, Labour in the Scientific Revolution - outlined a new vision of Britain, culminating in the party manifesto for the general election of 1964, The New Britain. These eloquently castigated Tory amateurism and incompetence: "With certain honourable exceptions, our finance and industry need a major shake up at the top. Too many directors owe their position to family, school or political connections. If the dead wood were cut out of Britain's boardrooms and replaced by the keen young executives, production engineers and scientists who are at present denied their legitimate prospects of promotion, our production and export problem would be much more manageable." They also linked Labour with a utopian vision of technology and prosperity: "This is our message for the Sixties - a Socialist inspired scientific 
and technological revolution releasing energy on an enormous scale." The talk of modernity and technology suffused the rhetoric of what Harold Wilson, Labour's leader, egregiously called "the white heat of the technological miracle." The language is best conveyed in this pastiche of ' 60 s Labour speeches:

Change... resurgence, a chance to sweep away the grouse-moor conception of Tory leadership and refit Britain with a new image... We are living in the jet age but we are governed by an Edwardian establishment mentality... clammy unimaginativeness at the top... clumsy, amateurish, ineffective and out-of-date, conservative, nostalgic, backward looking... need mobilization, a breakthrough to an exciting new period... streamlining, hard facts, storm the frontiers of knowledge... Britain's brashness and saltiness and political irreverence, energy and determination, in the age of automation, of jet and space travel. ${ }^{21}$

This vision was not just held by the revisionists who on other issues, such as unilateral disarmament, tended to take a conservative position. It was also found on the Left. Frank Cousins and Tony Benn, neither of them revisionists, both held Labour cabinet posts in science and technology. Indeed the critique of the old order held the Labour party together and helped them win the election of 1964, albeit with a tiny parliamentary majority.

This is not the place to rehearse the promises and failures of the Labour Party's vision - the rise and fall of the Department of Economic Affairs intended to manage the macro-economy, the radical increase in educational expenditure, the beginnings of a comprehensive system of education, and the fiscal restructuring in the manner suggested by Crosland. The chief feature of the first of Harold Wilson's administrations was no such reformist achievement but its state of perpetual crisis, largely the result of a balance of payment deficit and a run on sterling which the Left attributed to the hostility of the City to a Labour government.

The crisis kept the party together until the spring of 1966, when Wilson called an election and finally won a decisive majority. So that "New Ways in History" appeared at a time of great political ferment, in fact, one week after a general election in which the Labour Government finally had a proper political mandate.

\section{New Ways in History}

The Times Literary Supplement of 7 April 1966 was a special issue devoted to "New Ways in History." It consisted of twelve essays and an editorial designed to assess the state of history in Britain. Its cover, which I hope was ironic, included images of five British royals (William the Conqueror, the Black Prince, Henry VIII, Elizabeth I, Charles II), two British heroes (Nelson and Winston Churchill) and one foreign villain (Kaiser Wilhelm). Contributors included such luminaries of the Left as E. P. Thompson, writing on history from below, Eric Hobsbawm on history publishing, and Moses Finley (an American refugee from McCarthyism) on classical 
history. Other essays examined amateur history, art history, contemporary history, the histories of Latin America, Asia and Africa, and of ideas and technology. Omissions from today's perspective are striking: there was no women's history; neither cultural history nor science studies had a place in this critical survey; nor, more surprisingly did the history of the United States, an omission that reflected the parlous state of U.S. history in Britain in the 1960s. Broadly speaking the issue had two large themes. The first was epitomized in Moses Finley's remark that "sociological analysis not only complements and enhances more traditional approaches, it introduces radical correction"; the second in the repeated call for historical "relevance," for a history that addressed questions "which ordinary people wanted answering."22

The issue began with an essay by the young Oxford historian, Keith Thomas, brusquely entitled, "The Tools and the Job." ${ }^{23}$ Thomas's contribution, which framed the entire issue, was a passionate plea and bold prognostication - the historians' manifesto - for a new kind of history. Thomas painted a picture of a profession in crisis. (The language of crisis was even more fashionable in the 1960s than it is today.) Specialization and recondite scholarship had so fragmented the discipline that "for all its scholarly rigour, [it] had succeeded in explaining remarkably little about the workings of human society and the fluctuations of human affairs." "History was seen as a craft... It invoked no recondite conceptual tools, for commonsense and good judgment were all that was needed to understand the workings of human beings." ${ }^{24}$ Amateur, empiricist, focused on a political élite, history lacked vision and rigour. The desire for overarching explanation and broader understanding had driven one generation of historians (note the language of generations) - Christopher Hill, Rodney Hilton and Eric Hobsbawm - towards Marxism; it was now driving another towards the sciences of society - sociology, anthropology, demography and social psychology. Thomas framed his story as an account of a national failure to keep pace with the French, whose Annales School had linked history to the other social sciences, and with the Americans, who had a tradition of historical sociology. Historians in Britain - "they are decades behind their colleagues in other countries" ${ }^{25}$ - needed to refine their concepts in the light of social theory, to study statistics and the techniques of historical demography, and to learn from social anthropology how to investigate such irrational practices as witchcraft and crowd behaviour, and such small groups as villagers and peasant communities. Social, not political, history was to become the epicentre of historical studies. If historians were to keep up to date, a period of re-training was overdue.

Thomas's manifesto certainly looked revolutionary, realigning the historians' object of study - the peasant as much as the prince, society as a whole "not just its political elite," the rest of the world and not just the West - and transforming its method from a commonsensical procedure to an accurate science. Above all it heralded a marked shift in the attitude of historians to the social sciences. For much of the nineteenth and twentieth centuries those who had manned the good ship history had fought to repel sociologists and the like as unwanted intruders. Suddenly the old enemy was to be welcomed on board. Though today it seems tame (and, perhaps, misguided), 
Thomas's call was enormously controversial at the time. I remember one of my teachers disparaging Thomas as someone always telling us how to write history but not doing it himself - this was before the publication of his Religion and the Decline of Magic. And Thomas himself, though he now professes that he did not intend to stir controversy, and is at pains to deny that the issue as a whole was ever coordinated as a manifesto for historical change, ruefully admits that the issue and his contribution in particular caused quite a stir. ${ }^{26}$

The poetics of Thomas's essay are interesting: they are democratic and technocratic, scientific and progressive. The title lays down the gauntlet - The Tools and the Job. Gentlemen and amateurs do not use tools; they are not engaged in anything that approaches technical or manual labour. And the language of science pervades the essay: "Refined statistical techniques... precision... rigorous... demanding techniques of verification... objective... mathematically sophisticated tools of measurement... elaborate theoretical models... voluminous statistics... microscopic analysis... the age of the historical factory... technical training... new intellectual enterprises."27

Thomas's message, using the language of technology and enlightened social management, linked the new history to the larger processes of modernization. It presented history as a progressive not traditional discipline. This was politically shrewd as well as intellectually bold. For, in an era of university expansion in which the social sciences were seen as leading sectors in the new learning, history could claim its place in the intellectual vanguard. But it is noticeable that Thomas never explicitly acknowledges the politics of his position because he wants to move beyond a history moved by political engagement (exemplified by the Marxist historians of the previous generation) into the realm of objective, historical science.

The target of Thomas's critique was clear: the circumscribed, narrowly defined political history that comprised the core of the university curriculum that I was currently studying and which, as we have seen, dated back to the nineteenth century. The challenge, then, was to a key feature of the British establishment and to its ideological assumptions. And, of course, it struck a chord with the students who were, or saw themselves, as outside the old élite, who saw themselves as the beneficiaries of an ideology of merit. Indeed, one of the uniting themes of the contributions to "New Ways in History" was their repeated and implacable hostility to political history and to its narrative technique of telling the lives of the great. (It was this conflation between political history and narrative history that helps explain why for so long the latter had a bad name.)

But what was to replace political history? Thomas's criticism of "disintegrated history" and call for an understanding of "the workings of human society" implies a totalising history of the human species. This, according to Thomas, was not Marxism, which he gave high marks for boldness of vision, but low marks for its ability "to convey the complex realities of historical development." Possibly Thomas was thinking of the Annales School's claim to write total history. But there was more in his essay about the tools and much less about the job. 
Thomas's poetics of a scientific history posited a new sort of historian - both as student and professional. On the one hand it harked back to the old idea of history as an apposite training for the professional and governing classes, replacing woolly constitutionalism and common sense with technocratic egalitarianism, politics with society. On the other, it posited a new kind of technically trained, super-competent historian whose researches would contribute to a new general vision of the history of the social order. This new historian was something of a faceless creature - a man in a white coat (even if he was wearing a pink corduroy suit underneath it) someone with no features apart from his technical competence; he was once again a classless creature, the bearer and representative of a universal objectivity. It is no surprise that Thomas's vision was totalising; and it was no coincidence that he alluded explicitly to the conjectural social histories of the Scottish Enlightenment.

Though all the contributors to the special issue of the TLS were united by a shared hostility to traditional political history as elitist, narrow and irrelevant to modern society - the history of an outdated Establishment - there was less unanimity over the value of scientific history. (Though it is a sign of those times that even Edward Thompson, of all people, gestured towards the value of social science history.) Uneasiness about technocratic history took the form of fears that a more technical history would not be "intelligible and attractive to the layman," answering "the questions about history which ordinary people wanted answering," addressing issues that were "central and serious and relevant." 28 There was a persistent tension between the pressures to make history more technical and the desire to see it as democratically accessible to a broadbased citizenry.

The critics of old political history all agreed that the object of historical study should change. Over the next twenty years they were to realize this goal. (In my years as a young teacher in Cambridge in the 1970s, curricular reform - together with the opening of the university to more women were high on the agenda.) It became possible to explore the many realms of social experience, to write about the marginal and dispossessed, women and children, the criminal and insane, the irrational and obscure, the private and the intimate, and to have such studies treated seriously.

But this sort of history was not so much legitimated by an appeal to science, as couched in terms of a democratic relevance to ordinary people. It depended not on cool detachment and distance, but on engagement and intimacy. It sought historical truth, but rejected the view that science was the means by which it could be achieved. It encouraged emotional sympathy and identification with groups in the past in order to understand (and perhaps change) their position in contemporary society. This sort of historical writing was not new - indeed, in Britain it had a proud pedigree, celebrated in Edward Thompson's contribution to the $T L S$, in the Fabian, socialist, and Marxist writings on capitalism, poverty, labour and class struggle by the likes of Sidney and Beatrice Webb, R. H. Tawney, G. D. H. Cole, Donna Torr, H. L. Morton - but it was now diversified to include race, gender and sexual orientation. There was nothing terribly objective about this scholarship - it was passionate and committed - and it depended for much of its effect on 
dramatic historical narrative. It might be scientific in the socialist sense of embodying a theory of historical change, but, as its greatest practitioner of the 1960s and 1970s, E. P. Thompson, clearly demonstrated, it was resolutely literary and rhetorical in form, a bent that oddly enough was reinforced by post-structuralist versions of the French theory he affected to despise.

Scientific, technocratic history did not prove popular in Britain, even amongst some of its strongest proponents. ${ }^{29}$ (Thomas himself is a clear case in point.) Engaged pluralism, in this sphere, as in so many others, triumphed over a universal vision whose claim to truth apparently derived from its general objectivity. Though this is far from the whole explanation, its failure can, I think, be linked to the failure of socialist technocratic politics in Britain in the late 1960s and early 1970 s as well as to a growing skepticism about universal claims in both politics and academic inquiry. But for a while in the 1960s two very different historical visions (or, at least, so they appear in retrospect) were united against a traditionalist enemy in a modernizing project.

I don't want my account to appear too nostalgic. The contradictions inherent in the totalising vision of scientific socialism, Thomas's version of a new history, and pop culture's poetics of personal liberation are pretty obvious, and the criticisms directed against them seem very persuasive to me. But these different initiatives embody a moment in which it seemed possible to make a real break with the past and its traditions and, in a rather utopian (and naïve) way, to transform politics, society and history. They promised both freedom and power. Perhaps this was an (oedipal) adolescent fantasy and the 1960s (as has often been said) an adolescent decade, one abruptly thrust into maturity (not manhood) in 1968. But, though the different projects I have discussed were all, within their own terms, failures, they all had important unintended consequences - more important, perhaps, in culture and history than in politics, but sufficiently sweeping that conservative academics and social commentators still blame the woes of the present day on the ' 60 s.

More particularly, despite the conflict it occasioned, I have no regrets about having chosen my uncle's vision of history rather than my father's. Certainly the first book I wrote, Party Ideology and Popular Politics, ${ }^{30}$ was a deliberate and frontal assault on the traditional political history of elites and the figure, Sir Lewis Namier, who embodied its anti-theoretical traditions and contempt for equality. Namier admired Britain for its pragmatic traditionalism. The English, he said, "perceive and accept facts without anxiously enquiring into their reasons and meaning," a national virtue because "the less man clogs the free play of his mind with political doctrine and dogma, the better for his thinking." As for the populace, "there is no free will in the thinking of the masses, any more than in the revolutions of the planets, in the migrations of birds, and in the plunging of hordes of lemmings into the sea." ${ }^{31}$ Such views were anathema to me, and Party Ideology was devoted to the proposition that ideas and arguments in politics count and that even in the eighteenth century, long regarded as an era of delightful, oligarchic complacency, they were vigorously debated by many beyond the political elite. Similarly almost all the work I have pursued on the cultures of consumption is coloured by an abiding sense that commercialized, 
popular and mass consumption - like the pop culture of the 1960s - is an important source of creativity that deserves serious historical analysis. ${ }^{32}$ And last, but not least, my foray into the history of eighteenth-century state formation, bureaucracy and the politics of information, though hardly a study of the "white heat of the technological miracle," was informed by a strong sense of the technical powers of governing and of information management. I don't want to exaggerate the continuities between my experiences in the 1960s and my writing thereafter. I'm leery of creating a tidy genealogy of anyone's intellectual development. But I can occasionally detect in my historical writing the impress of those events of 1966 that as Benjamin says - "underlie... [the historian's] presentation like a text written in invisible ink." 
${ }^{1}$ Cf. Walter Benjamin, Das Passagen-Werk. Frankfurt am Main: Suhrkamp, 1991, vol. 1, p. 595 [N 11, 3]: "Das Geschehen, das den Historiker umgibt und an dem er teil nimmt, wird als ein mit sympathetischer Tinte geschriebener Text seiner Darstellung zu Grunde liegen."

${ }^{2}$ Times Literary Supplement (TLS), 7 April (1966), "New Ways in History", pp. 275-310.

${ }^{3}$ Colin Wilson, The Outsider. London: Victor Gollancz, 1956.

${ }^{4}$ Cf. Anthony Sampson, Anatomy of Britain. London: Hodder and Stoughton, 1962, p. 620: "All through this book I have felt haunted by the Victorians."

${ }^{5}$ David Wainwright, Liverpool Gentlemen. A History of Liverpool College, An Independent Day School From 1840. London: Faber and Faber, 1960.

${ }^{6}$ For these developments see Phillipa Levine, The Amateur and Professional. Antiquarians, Historians and Archaeologists in Victorian Britain 1838-1886. Cambridge: Cambridge University Press, 1986 and John Kenyon, The History Men. The Historical Profession in England since the Renaissance. London: Weidenfeld and Nicholson, 1983, esp. chapter 5.

${ }^{7}$ Cited in Kenyon, The History Men, p. 179.

${ }^{8}$ Cited in Kenyon, The History Men, p. 296.

${ }^{9}$ Cited in Levine, The Amateur and Professional, p. 160.

${ }^{10}$ Cited in Kenyon, The History Men, p. 170.

${ }^{11}$ Cited in Kenyon, The History Men, p. 278.

${ }^{12}$ George Melly, Revolt into Style. The Pop Arts in Britain. London: Allen Lane The Penguin Press, 1970.

${ }^{13}$ Compare the Liverpool poet Roger McGough's "Let me die a youngman's death," in Edward Lucie-Smith (ed.), The Liverpool Scene. London: Donald Carroll, 1967, p. 47.

${ }^{14}$ Edward Lucie-Smith (ed.), The Liverpool Scene, cited on rear cover. I assume the quote is not apocryphal.

${ }^{15}$ Adrian Henri, "Me," in The Liverpool Scene, p. 42.

${ }^{16}$ Karl Marx: selected writings in sociology and social philosophy, newly translated by T.B. Bottomore; edited with an introduction and notes by Mr. Bottomore and Maxamilien Rubel. London: Watts, 1956.

${ }^{17}$ C. A. R. Crosland, The Future of Socialism. London: Jonathan Cape, 1956.

${ }^{18}$ Crosland, The Future of Socialism, p. 504.

${ }^{19}$ Antony Sampson, Anatomy of Britain. London: Hodder and Stoughton, 1962, esp. pp. 632-3. Henry Fairlie offered what was perhaps the best definition: "By 'the Establishment' I do not mean only the centres of official power - though they are certainly a part of it - but rather the whole matrix of official and social relationships within which power is exercised." Cited in Oxford English Dictionary. Vol. V. 2nd ed. Oxford: Clarendon Press, 1989, p. 405.

${ }^{20}$ Crosland, The Future of Socialism, p. 505.

${ }^{21}$ Harold Wilson, The New Britain. London: Penguin Books, 1964, esp. pp. 9-13, 15-16, 33-4, 130-2.

22 “New Ways in History," pp. 290, 295.

${ }^{23}$ Thomas has pointed out to me that this was not his title, but added by the editor. He sees it as a reference to Churchill and does not construe it as I do. He also says that he was not a party to the decision to run his piece as the headline article of the issue. (Personal communication, 19 September 2001.) 


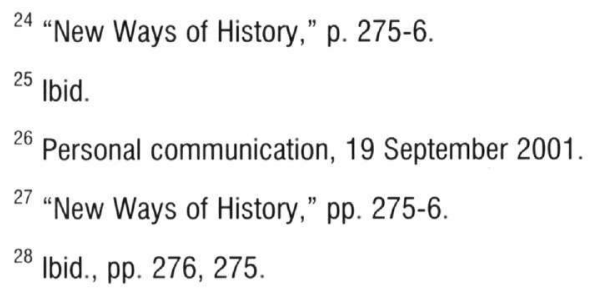

${ }^{29}$ An excellent sense of the rift between empathic social history and social science history can be found in Roderick Floud's essay regretting the divide. (Roderick Floud, "Quantitative History and People's History. Two methods in conflict?" Social Science History, 8:2 [1984], pp. 151-168.)

${ }^{30}$ John Brewer, Party Ideology and Popular Politics at the Accession of George III. Cambridge: Cambridge University Press, 1976.

${ }^{31}$ Quoted in Perry Anderson, "Components of the National Culture," in English Questions. London: Verso, 1992, pp. 63, 76. Anderson's essay, first published in New Left Review, 50 (May/June 1968), pp. 3-57, well conveys the central importance of Namier. His discussion of the state of history in the 1960s focuses almost exclusively on Namier, who is also taken to exemplify the influx of conservative intellectuals into Britain from continental Europe.

${ }^{32}$ This is not to adopt a credulous aesthetic populism but to challenge the view, present in both left-and rightwing aesthetics, that commerce necessarily taints culture. Such a position marginalizes what is central to modern culture, fails to grapple with the important contradiction that lies at the heart of the distribution of cultural capital, and occludes the making of critical judgments about particular cultural artefacts. See Ann Bermingham, "Introduction" in Ann Bermingham and John Brewer (eds.), The Consumption of Culture. Image, Object, Text. London: Routledge, 1995, pp. 1-20. 